\section{Effect of Ethisterone, $\beta$-CEstradiol and Progesterone on the Phagocytic Activity of the Reticulo-Endothelial System}

The reticulo-endothelial cells are known to form an important part of the defence mechanism of the body against infection. At the site of acute infections, neutrophil leucocytes attack the invading organisms while the reticulo-endothelial macrophages phagocytose the dead bacteria and dead tissue cells. In chronic infections such as tuberculosis, the phagocytic activity of the macrophages forms the main line of defence against the invading organisms. Further, there is much circumstantial evidence in both acute and chronic infections to show that the reticulo-endothelial cells raise the humoral resistance of the patient by the production of antibodies. It has already been demonstrated that the phagocytic activity of the reticulo-endothelial system is stimulated by œstrogens ${ }^{1}$; that cortison ${ }^{2}$, testosterone, androsten $\Theta-3 \beta-17 \alpha$-diol ${ }^{3}$ depress the phagocytic activity; and that deoxycorticosteron $\theta^{4}$ has no appreciablo effect.

The present communication deals with the effects of ethisterone, $\beta$-cestradiol and progesterone. Fortythree male guinea pigs were used. The reticuloendothelial macrophages were studied by giving all the animals one daily injection of trypan blue subcutaneously for the last six days prior to being killed by chloroform. The dosage of the dye was calculated on the basis of $0.8 \mathrm{ml}$. of a 1 per cent solution in distilled water per $100 \mathrm{gm}$. bodyweight. Seven of the animals were given dye only and were used as controls. The hormone treatment given to the remaining thirty-six animals is shown in Table 1.

Table 1. Hormone TraatMent GIVRN to ThIRTY-six ANIMALS

\begin{tabular}{|c|c|c|c|}
\hline $\begin{array}{c}\text { No. of } \\
\text { animals }\end{array}$ & Hormone used & $\begin{array}{c}\text { Daily dose } \\
\text { intra- } \\
\text { muscularly }\end{array}$ & $\begin{array}{c}\text { Duration } \\
\text { of } \\
\text { treatment }\end{array}$ \\
\hline 6 & $\begin{array}{l}\text { Ethisterone (Organon) dis- } \\
\text { solved in ethyl oleate }\end{array}$ & $0.5 \mathrm{mgm}$ & 2 weeks \\
\hline 6 & $\begin{array}{l}\text { Ethisterone (Organon) dis- } \\
\text { solved in ethyl oleate }\end{array}$ & $0.5 \mathrm{mgm}$. & 4 weeks \\
\hline 6 & $\begin{array}{l}\beta \text {-Gotradiol (Organon) dis- } \\
\text { solved in ethyl oleate }\end{array}$ & $0.5 \mathrm{mgm}$. & 2 weeks \\
\hline 6 & $\begin{array}{l}\beta \text {-CEstradiol (Organon) dis- } \\
\text { solved in ethyl oleate }\end{array}$ & $0.5 \mathrm{mgm}$ & 4 weeks \\
\hline 6 & $\begin{array}{l}\text { Progesterone (Organon) dis- } \\
\text { solved in ethyl oleate }\end{array}$ & $5.0 \mathrm{mgm}$ & 2 weeks \\
\hline 6 & $\begin{array}{l}\text { Progesterone (Organon) dis- } \\
\text { solved in ethyl oleate }\end{array}$ & $3.0 \mathrm{mgm}$. & 3 weeks \\
\hline
\end{tabular}

Specimens were taken from the splean, liver and lymph nodes and fixed in Heidenhain's Susa fluid. Sections were cut at $10 \mu$ thick and stained with weak eosin, dilute carbol fuchsin or alum carmine. The activity of the reticulo-endothelial system in the organs studied was assessed by the number of dyebearing cells and the intensity of the vital staining.

In the animals which received ethisterone and $\beta$-cestradiol, a moderate number of dye granules was present in the macrophages of the spleen, liver and lymph nodes and the vital staining appearances closely resembled those in the control animals. In the six animals which received $3 \mathrm{mgm}$. of progesterone daily for three weeks the vital staining appearances were similar to those of the controls. In the group which received $5 \mathrm{mgm}$. of progesterone daily for two weeks, four showed vital staining appearances similar to the controls, while the remaining two animals showed reduced activity of the macrophages.

The results, therefore, suggest that, in the male guinea pig, ethisterone, $\beta$-œstradiol and progesterone have little or no effect on the activity of the reticuloendothelial system and in this respect differ greatly from the estrogens.

The substances used in these investigations were provided by Dr. Tindall, of Organon Laboratories, Ltd., to whom we offer our grateful thanks.

T. NrCOL

R. S. SNELI

Department of Anatomy, King's College,

London, W.C.2. Nov. 9.

Nicol, T., Helmy, I. D., and Abou-Zikry, A., Brit. J. Surg., 40, 166 (1952).

Nicol, T., and Snell, R. S., Nature, 174, 554 (1954); 177, 430 (1956).

${ }^{3}$ Snell, R. S., and Nicol, T., Nature [178, 1405 (1956) ].

4 Nicol, T., and Snell, R. S., Nature, 175, 995 (1955).

\section{Isolation of Nigerose from Floridean}

IT is generally agreed that the iodine-staining polysaccharide isolated from many red algae is a glucan of the amylopectin type in which the chainforming links are $\alpha-1: 4$ and the branch links, $\alpha-1: 6$-glucosidic. The floridean starch from Dilsea edulis appears to differ, in finer details of structure, from one sample to another. This difference turns mainly on the presence or the absence of a third type of link, namely, the 1:3-glucosidic linkage ${ }^{1}$. The majority of investigations favour the view that 1:3-glucosidic linkages are in fact not present in Dilsea starch ${ }^{2}$. We therefore think it desirable to record some observations made in the course of a comprehensive linkage analysis of floridean starch which establish that a small proportion of $1: 3$-links is an integral part of the starch structure and, moreover, that these links have the $\alpha$-configuration.

Floridean starch was extracted from Dilsea edulis by the method of Barry et al. ${ }^{1}$ and was purified by precipitation with iodine ${ }^{3}$ and by use of cetyl trimethyl ammonium bromide ("Cetavlon') to precipitate a galactan sulphate impurity ${ }^{4}$. The starch $(92.5$ per cent polyglucose) had $[\alpha]_{D}^{18}+187^{\circ}$ (water) and blue value, 0.065 . The starch $(12.5 \mathrm{gm}$.) was hydrolysed by $0.33 \mathrm{~N}$ sulphuric acid $\left(\mathbf{1 . 2 5}\right.$ litres) at $100^{\circ}$ to the stage of an apparent conversion into glucose of 53.4 per cent $(2 \cdot 15 \mathrm{hr}$.). After being cooled, neutralized and concentrated, the hydrolysate was chromatographed on a column of charcoal-'Celite's. Glucose was the only monosaccharide obtained, but the disaccharides were readily separated into two fractions, the first consisting almost entirely of isomaltose $(289 \mathrm{mgm}$.), characterized as its $\beta$-octaacetate (melting point $142 \cdot 3^{\circ} ;[\alpha]_{D}^{18}+96 \cdot 9^{\circ}$ in chloroform). The second disaccharide fraction was mainly maltose but contained a small amount of another disaccharide, which was separated from the maltose by taking advantage of its greater electrophoretic mobility in borate buffer ${ }^{6}$. The amorphous solid obtained (34.6 mgm.) migrated as a single substance during both paper chromatography and electrophoresis and had mobilities in each system identical with those of authentic nigerose. It showed $[\alpha]_{D}^{18}+136 \cdot 9^{\circ}$ (water) and its $\beta$-octa-acetate had melting point and mixed molting point $147-48^{\circ}$ and 